oło Naukowe Specjalistów Informacji (dalej: KNSI), działające przy Instytucie Informacji Naukowej i Bibliologii Uniwersytetu Mikołaja Kopernika w Toruniu (dalej: INiB), w roku akademickim 2009/2010 starało się kontynuować założenia oraz plany z roku poprzedniego, a także realizować nowe projekty. Był to rok uczestnictwa $\mathrm{w}$ wielu konferencjach zarówno w kraju, jak i za granica, zmian personalnych w składzie zarządu Koła i związanej z tym rekrutacji nowych członków oraz poszukiwania nowych możliwości współpracy z innymi kołami naukowymi.

Pierwsze spotkanie w semestrze zimowym poświęcono na wybór nowego zarządu Koła, a także obsadę stanowiska redaktora naczelnego biuletynu „WERSALIK.TXT” - nieregularnika wydawanego przez Koło. W wolnych i tajnych wyborach ukształtowały się nowe władze: Paweł Wróblewski prezes, Rafał Jerzy Jurkowski - zastępca prezesa, Irmina Obermüller - sekretarz/skarbnik. Jednogłośnie wybrany został również redaktor biuletynu, którym została studentka czwartego roku informacji naukowej i bibliotekoznawstwa Aleksandra Stefańska. Już na początku października zadbano także o ustalenie planu działania na cały rok akademicki. Wśród przewidzianych inicjatyw znalazły się: pomysł zorganizowania w Toruniu ogólnopolskiej konferencji studenckich kół naukowych, wydawanie kolejnych numerów

\section{Działalność Koła Naukowego Specjalistów Informacii w roku akademickim 2009/2010}

biuletynu, uczestnictwo w konferencjach kół naukowych, a także przygotowanie referatów na międzynarodowe sympozjum BOBCATSSS. Ponadto członkowie Koła podjęli decyzję o rozpoczęciu akcji promującej działalność Koła i zachęcającej do wstępowania w jego szeregi. W związku z tym opracowano projekt plakatu, a także ulotek adresowanych do studentów informacji naukowej i bibliotekoznawstwa.

Priorytetem w działalności Koła stało się jednak przygotowanie ogólnopolskiej konferencji kół naukowych. Konsultując decyzje z pracownikami Zakładu Informacji Naukowej INiB, ustalono temat spotkania - „Biblioteka 2.0 - i co dalej?", jego zakres merytoryczny (nowe technologie i kierunki rozwoju bibliotek w kontekście sieci drugiej generacji, nowe formy bibliotek, użytkownik a nowoczesna biblioteka) oraz termin - 16 kwietnia $2010 \mathrm{r}$. Aby rozpowszechnić informację o tym wydarzeniu, w ramach serwisu informacyjnego studentów i fascynatów informacji i bibliologii WERSALIK stworzono odrębną stronę WWW dedykowaną konferencji.

W pierwszych miesiącach nowego roku akademickiego zespół redakcyjny „WERSALIKA.TXT” pracował 
także nad wydaniem drugiego numeru czasopisma. Ukazał się on na początku grudnia 2009 r. i obejmował sześć artykułów, poświęconych problematyce portali społecznościowych (Ewelina Wojciechowska), dostępności stron internetowych dla niewidomych (Anna Pluta), zmianom dokonującym się w Internecie pod wpływem rozwoju nowoczesnych technologii (Paweł Wróblewski), zawodowi brokera informacji (Aleksandra Stefańska), nowym funkcjom przeglądarki Mozilla Firefox (Irmina Obermüller) oraz samej historii i idei powołania serwisu Koła WERSALIK (Rafał Jerzy Jurkowski).

Koniec roku 2009 przyniósł uczestnictwo członków Koła w dwóch konferencjach studenckich. Pierwszą z nich była krakowska VI Ogólnopolska Konferencja Studenckich Kół Naukowych, zorganizowana 27 listopada pod tytułem „Information Literacy. W świetle potrzeb XXI wieku". Przedstawiciele toruńskiego bibliotekoznawstwa zaprezentowali na niej dwa referaty: „Ask a librarian - zapytaj bibliotekarza wirtualne usługi świadczone przez bibliotekarzy” (Anna Pluta) oraz „Bibweb - doskonalenie warsztatu bibliotekarza XXI wieku" (Rafał Jerzy Jurkowski, Irmina Obermüller, Paweł Wróblewski). Drugim spotkaniem, w którym wzięli udział członkowie KNSI, była - przygotowana 14 grudnia 2009 r. przez Koło Naukowe Bibliotekoznawców Uniwersytetu Kazimierza Wielkiego w Bydgoszczy - Ogólnopolska Konferencja Studenckich Bibliologicznych Kół Naukowych pod hasłem „Librarius czy information manager?”. Bibliolo- dzy z Torunia i tym razem wygłosili dwa referaty. Pierwszy z nich, autorstwa Eweliny Wojciechowskiej i Pawła Wróblewskiego, analizował szkolenia biblioteczne przeprowadzane za pomocą Internetu i nosił tytuł „Szkolenie biblioteczne on-line, czyli e-learning w bibliotece", drugi - referowany przez Rafała Jerzego Jurkowskiego i Irminę Obermüller - dotyczył działalności Koła i realizowanych przez nie projektów. Wystąpienia studentów z Torunia cieszyły się dużym zainteresowaniem uczestników obydwu konferencji, a one same stały się nie tylko szansą na nawiązanie licznych kontaktów międzyuczelnianych, ale także okazją do zapowiedzi organizacji podobnego wydarzenia w Toruniu.

Nowy rok kalendarzowy (2010) rozpoczął się niezwykle intensywnie dla Koła. Pod koniec stycznia dwóch przedstawicieli zarządu (Rafał Jerzy Jurkowski, Paweł Wróblewski) miało przyjemność uczestniczyć w sympozjum BOBCATSSS w Parmie - spotkaniu organizowanym co roku przez sieć instytucji kształcących w dziedzinie informacji naukowej i bibliotekoznawstwa. Tegoroczna edycja konferencji, odbywająca się pod hasłem „Bridging the digital divide: libraries providing access for all?” (pol. „Zapobieganie wykluczeniu cyfrowemu: biblioteki jako miejsca zapewniające dostęp dla wszystkich?") była już osiemnastą $\mathrm{z}$ kolei. Tradycyjnie $\mathrm{w}$ jej programie nie zabrakło także wystąpień studentów z Torunia. Tym razem przybliżyli oni zgromadzonym serwisy studentów informacji naukowej i bibliologii 
kształtujące społeczność okołobiblioteczną. Udział w sympozjum był źródłem cennych doświadczeń dla członków zarządu Koła, dostarczył bowiem nie tylko wiedzy merytorycznej, ale także przykładów rozwiązań, które można przenieść na grunt polski podczas organizacji podobnych imprez.

Kolejne trzy miesiące roku akademickiego pochłonęły przygotowania do organizacji i sam przebieg Ogólnopolskiej Konferencji Studenckich Kół Naukowych „Biblioteka 2.0 - i co dalej? - nowe technologie i rozwiązania w bibliotekach". Odbywające się dnia 16 kwietnia 2010 r. spotkanie zgromadziło około 150 osób - studentów z Krakowa, Warszawy, Lublina, Katowic, Bydgoszczy i Torunia. W ciągu ośmiu godzin i dwóch sesji wygłoszono łącznie dziesięć referatów. Ich autorzy poruszali m.in. następujące tematy: „Nowe technologie w służbie czytelnictwu osób z dysfunkcją narządu wzroku" (Marek Deja, Uniwersytet Kazimierza Wielkiego w Bydgoszczy), „Internetowe narzędzia interakcji z czytelnikami $\mathrm{w}$ serwisach WWW bibliotek województwa małopolskiego" (Małgorzata Jaskólska, Natalia Toczek, Uniwersytet Jagielloński), „E-learning i mind mapping jako nowe wyzwania edukacyjne dla bibliotek" (Agnieszka Grzegorczyk, Agnieszka Posłajko, Uniwersytet Marii Curie-Skłodowskiej w Lublinie), „Jak wygrać z torrentami? - proponowane kierunki rozwoju dla polskich bibliotek cyfrowych" (Jacek Włodarski, Uniwersytet Warszawski), „Elektroniczne bazy danych w zasobach Wyższej Szkoły Bankowej w Toruniu: metody udostępniania, promocja i wykorzystanie" (Ewelina Wojciechowska, Anna Wydrzyńska, INiB). Wart podkreślenia jest fakt, że każde z wystąpień wywoływało żywą dyskusję, a toruńska konferencja jako jedna z nielicznych studenckich inicjatyw tego typu miała Radę Naukową, w skład której weszli pracownicy naukowi INiB. Po sukcesie spotkania Koło Naukowe Specjalistów Informacji powzięło decyzję o organizacji podobnego przedsięwzięcia w roku następnym.

Kwiecień upłynął jednak nie tylko pod znakiem Ogólnopolskiej Konferencji Studenckich Kół Naukowych, ale także udziału w Targach Kół Naukowych organizowanych przez Fundację Amicus. W ich ramach przedstawiciele Koła propagowali swoją działalność oraz pozyskiwali nowych członków. Niestety, targi cieszyły się umiarkowanym zainteresowaniem, $\mathrm{w}$ związku z czym przygotowane przez Koło ulotki, plakaty i prezentacje multimedialne nie znalazły wielu odbiorców.

Ostatnie dwa miesiące roku akademickiego 2009/2010 poświęcono na pracę nad serwisem WERSALIK. Dążono do tego, aby stał się on bardziej przejrzysty i ciekawszy dla użytkowników. W tym celu całkowicie zmieniono jego wygląd i strukturę, wprowadzono nowe rozwiązania, zrezygnowano z mniej popularnych działów na rzecz rozwijania tych atrakcyjniejszych i częściej odwiedzanych. Aby serwis wpisywał się w koncepcję Web 2.0, stworzono forum i umożliwiono zakładanie kont pocztowych w celu usprawnienia 
kontaktów tworzącej się wokół serwisu społeczności. Zmiany przeprowadzone pod nadzorem Rafała Jerzego Jurkowskiego przyniosły oczekiwany efekt i zwróciły uwagę wielu internautów oraz twórców serwisów internetowych (portal Pulowerek.pl zamieścił na swoich stronach informację o nowym wcieleniu WERSALIKA).

Podsumowując, warto zauważyć, że rok akademicki 2009/2010 był niezwykle pracowity dla Koła Naukowego Specjalistów Informacji. Choć realizacja wielu projektów wymagała od członków Koła czasu, energii i zaangażowania, to trud i wysiłek przyniósł pełną satysfakcję z dobrze wykonanej pracy. Uczestnictwo w licznych konfe- rencjach w kraju i za granicą pozwoliło studentom nie tylko na poszerzenie horyzontów i doprecyzowanie zainteresowań naukowych, ale także na doskonalenie umiejętności wystąpień publicznych. Należy żywić nadzieję, że kolejny rok działalności będzie równie owocny jak ubiegły, a pomysły i determinacja członków Koła staną się gwarantem powodzenia.

\section{Paweł Wróblewski}

student I roku uzupełniajacych studiów magisterskich z zakresu informacji naukowej i bibliotekoznawstwa w Instytucie Informacji Naukowej i Bibliologii Uniwersytetu Mikołaja Kopernika w Toruniu
W ramach współpracy Unii Europejskich Federalistów, Instytutu Goethego oraz Stowarzyszenia Bibliotekarzy Polskich w dniach 7-11 czerwca 2010 r. odbył się wyjazd studyjny do bibliotek niemieckich. Bibliotekarze $\mathrm{z}$ całej Polski oraz pracownicy uczelni wyższych (łącznie 24 osoby) mieli okazję poznać sposób i zasady funkcjonowania dziesięciu bibliotek z terenu Saksonii oraz Turyngii. Wizytowano m.in. Bibliotekę Miejską w Bautzen (Stadtbibliothek Bautzen), Centrum Metodyczno-Informacyjne dla bibliotekarzy z Turyngii w Erfurcie (Landesfachstelle für Öffentliche Bibliotheken in Thüringen),

${ }^{1}$ Wszelkie dane zamieszczone w relacji pochodzą od bibliotekarzy z wizytowanych bibliotek niemieckich.

\section{Biblioteki Saksonii i Turyngii \\ - europejskie centra multimedialne. Wyjazd studyjny członków Stowarzyszenia Bibliotekarzy Polskich do bibliotek niemieckich'}

Bibliotekę Miejską i Centrum Regionalne w Erfurcie (Stadt- und Regionalbibliothek Erfurt), Filię Dziecięcą Biblioteki Miejskiej w Erfurcie, Bibliotekę Szkolną w Erfurcie, Bibliotekę Szkoły Wyższej w Mittweida, Bibliotekę Miejską w Mittweida (Stadtbibliothek Mittweida), Bibliotekę Uniwersytecką w Dreźnie (Sächsische Landesbibliothek - Staats- und Universitätsbibliothek Dresden), Miejską Bibliotekę w Dreźnie i Mediatekę oraz 